\title{
THE PRINCIPLE OF PRESUMPTION OF INNOCENCE AND PROSECUTION POLICY
}

\author{
M . Haryanto, SH.,M.Hum
}

Faculty of Law, Satya Wacana Christian University

\begin{abstract}
The issue IF this article is to be addressed in this article is the incompatibility between the prosecution policy issued by the Supreme Prosecutor's Office of the Republic of Indonesia and the principle of presumption of innocence. This article finds that the General Attorney's Office disregards the principle of presumption of innocence recognized by the Criminal Procedural Law by issuing General Attorney Directive on Criminal Prosecution and General Attorney Notice dispatched to the Head of High Prosecutor's Office which denied the Prosecutor's authority to request for acquittal in a criminal litigation. To solve this issue, the author argues that in a case where the evidence did not support the prosecution in relation with the existence of the crime or the perpetrator who is not the convicted, the Prosecutor should embrace the principle of presumption of innocence and consequently request for acquittal of the accused or convicted.
\end{abstract}

Key Words: Presumption of Innocence; Prosecution Policy

\section{A. INTRODUCTION}

This article aims to study the prosecution policy of the office of attorney of the Republic of Indonesia. In directing or controlling the prosecutorial functions exercised by the officers under him, the Attorney General published a prosecution policy that is packaged in the form of Circulars of the Attorney General (hereinafter referred to as SEJA, stands for Surat Edaran Jaksa Agung). The Attorney General's prosecution policy of the Republic of Indonesia include the following circulars:

a. Circular of the Attorney General of the Republic of Indonesia Number: SE-009 / JA / 12/1985 on Guidelines for Criminal Charges (December 14, 1985).

b. Circular of the Attorney General of the Republic of Indonesia Number: SE-001 / J-A / 4/1995 on Guidelines for Criminal Charges (27 April 1995).

c. Circular of the Attorney General of the Republic of Indonesia Number: SE-001 / JA / 2/1999 on Guidelines for Conditional Punishment Charges in Corruption Cases (February 5, 1999). 
d. Circular of the Attorney General of the Republic of Indonesia Number: SE-003 / A / JA / 05/2002 on the Amendment of Control of Charges of Special Crime (May 13, 2002).

e. Circular of the Attorney General of the Republic of Indonesia Number: SE-005 / A / JA / 08/2003 on Dead Penalty Charges (August 25, 2003).

f. Circular of the Attorney General of the Republic of Indonesia Number: SE-006 / A / JA / 08/2003 on Acquittal (August 25, 2003).

The problems or legal issues that are established as the focus of this article is the suitability of the prosecution policy with the principle of presumption of innocence, which is at the heart of Indonesia's Criminal Procedural Law as it is stipulated in Law No. 8 of 1981 on the Law of Criminal Procedure (hereinafter referred to as the Criminal Procedural Law).

The motivation of the writer to question the prosecution policy of the Attorney General of the Republic of Indonesia is the tendency in the office of prosecutors to charge the defendant guilty simply to align with the "command" of SEJA rather than to rely on the results of the evidentiary hearing before the trial court. 'the Letter of Attorney General to the Head of High Prosecutor Office, No. B-572 / E / 10/1994, dated October 7, 1994)

In such a situation, the potential deviation or violation of the principle of presumption of innocence by the prosecution policy of the Attorney General of the Republic of Indonesia is greater even when the results of the examination of evidence before the trial court stated otherwise. The public prosecutor was unable to prove that the accused was guilty before the trial but still charged the defendant guilty. This unfortunately gives the impression that the office of the prosecutor prosecutes arrogantly or arbitrarily. Therefore, to criticize this, the author argues that the prosecution policy of the Attorney General of the Republic of Indonesia which tends to "force" the Public Prosecutor to prosecute the accused guilty need to be corrected as a form of internal reforms to restore the image of the Prosecutor of the Republic of Indonesia as a whole by showing that the prosecutors adhere to the principles contained in the Criminal Procedural Law, in particular the presumption of innocence principle. 


\section{B. PROBLEM STATEMENT}

In defending the argument, the discussion of this article is developed according to the following systematics. First, the author will explain the nature of the presumption of innocence principle and also argued that the principle is very important in the Criminal Procedural Law and needs to be to be respected by all law enforcement officers. Second, the author will discuss and explain the substance of prosecution policy in SEJA issued by the Attorney General of the Republic of Indonesia and analyse it in connection with the principle of presumption of innocence. Thirdly, the author will provide recommendations on the need for a change in prosecution policy of the Attorney General's Office of the Republic of Indonesia so that this institution respect and abide more by the principle of presumption of innocence.

\section{DISCUSSION}

\section{The Principle of Presumption of Innocence in Criminal Procedural Law}

Criminal Procedural Law are a set of principles and rules of law governing the authority of the state to punish when criminal laws are violated. From that sense, it can be seen that in the Criminal Procedural Law contains principles and rules that must be followed by all those involved in the implementation of the law. Broadly speaking, the principle of law is the basic idea of a general nature which is the background or the foundation for the establishment of the rule of law. According to van der Velden, principle of law is a type of decision that are used as benchmarks to assess the situation or be used as a guideline to behave. (www.scribd.com/doc/56939217/Asas-asas -hukum, p. 2.)

One of the principles that are used as benchmarks in the Criminal Procedural Law of Indonesia to assess the behavior of those involved in it, especially law enforcement officers such as investigators, prosecutors, defense counsel and the judge is the principle of presumption of innocence. The formulation of the presumption of innocence in the Criminal Procedural Law does not explicitly stated in its articles, but is found in the General Explanation of the Criminal Procedural Law number 3 letter c, which reads as follows: "Any persons suspected, arrested, detented, prosecuted and/or confronted in the courtroom 
court, shall be presumed innocent until the court ruling that declared his guilt gains permanent legal power." (Abdul Hakim G. Nusantara dkk, 1996: 96.)

The principles contained in the General Explanation of the Criminal Procedural Law is an integral part of the Criminal Procedural Law itself. Those principles must be followed by law enforcement agencies in the enforcement of the Criminal Law. This notion could be inferred from De Bosch Kemper's opinion on the meaning of the Criminal Procedural Law, namely: "a number of principles and rules of law governing the state's authority to punish when criminal laws violated." (M. Haryanto, 2007: 1.)

What is described above is also in line with the opinion of Yahya Harahap that: "The principle or the principle of 'presumption of innocence', could be found in a general explanation item 3 letter c. With the inclusion of the presumption of innocence in the explanation of the Criminal Procedural Law, it can be concluded that lawmakers have adopted it as the underlying legal principles of the Criminal Procedural Law" (Yahya Harahap, 1985:38-39.). Furthermore, with regard to the function of the presumption of innocence as a guide for law enforcement officers, Yahya Harahap also said:

The existence of the principle of presumption of innocence in the Criminal Procedural Law provides guidance to law enforcement officials to apply the acussatorial principle in every level of examination. Law enforcement officials must abstain from being inquisitor that puts the suspect / defendant in any investigation as an object that can be treated arbitrarily. Inquisitorial principle was previously used in criminal law examination at the time of HIR. HIR did not provide a right and a reasonable opportunity for the suspect / accused to defend themselves and defend their rights and hold the truth. Since the beginning, the law enforcement officers adopt the following attitude:

already assumed a priori that the suspect / defendant is guilty, as if the suspect has been punished since the first moment he was questioned before the investigation authorities.suspect / defendant is considered and treated as an object of inspection regardless of his basic human rights and his right to defend and maintain its dignity and truth. Consequently, it is often the case in law enforcement practices that a truly innocent person is forced to accept his misfortune in jail. One infamous example involved the case of Karta and Sengkon, who had curled up serving a few years for a murderperformed by someone else (Yahya Harahap, 1995:39).

Based on the literature and legal research as well as by studying some cases, Mien Rukmini suggested that the meaning of the principle of presumption of innocence is as follows: 
... The true meaning contained in this principle is that each person, with no exception, who are designated as a suspect, arrested, detained, put in investigation, prosecution, trial, shall be presumed innocent until his guilt is declared in a court decision that already has permanent legal force. ${ }^{1}$

From the definition of the presumption of innocence principle, it is understandable that in the judicial process, starting from the inquiry stage, investigation, prosecution and examination before the court, each law enforcement officers is obliged to recognize that the suspect or the accused was not definitively guilty as the perpetrators of the charged crminal act and may only be found guilty as the perpetrators of the act as indicted by the public prosecutor, if through the process of examination before the court, the judge in his ruling declared him as guilty as charged by the prosecutor, and that the judge's decision has gain binding force.

What is meant by the judge's decision in this paper is a court verdict or vonnis, which in the Criminal Procedural Law is defined as: "... a statement of the judge pronounced in an open court, which can either contain punishment or acquittal in a case according to manner contemplated in this legislation" (Mien Rukmini, 2003: 179). Having regard to the notion that the principle of presumption of innocence is associated with the a court verdict, the defendant is not necessarily be found guilty of committing criminal offenses as charged by public prosecutor, but based on the court examination the judge may choose one of three (3) alternate verdict: free, acquittal and punishment.

Considering that the principle of presumption of innocence must be followed in enforcing the Criminal Law, this principle applies not only to judges, but also apply to the public prosecutor who filed the accusation. Thus, according to the presumption of innocence principle, the prosecutor is as such "not obliged" to declare the defendant guilty of the offenses charged and sentenced by judges. Based on the process of examination, it is also possible for the public prosecutor to prosecute free or to submit acquittal.

Based on the description above, the legislators of the Criminal Procedural Law has provided a protective shield to the suspect / defendant in the form of 
rights that provide the legal position which is equal with to criminal law enforcement officers. This is in line with the views Yahya Harahap as follows:

How to guarantee that the principle of presumption of innocence and the accusatorial principle be enforced at all levels of the examination process? To sustain the presumption of innocence and the accusatorial principle in law enforcement, the Criminal Procedural Law already provide shield for the suspect / defendant in the form of a set of human rights that must be respected, protected by the law enforcement officers. With a shield of rights recognized by the law as residing in a suspect / defendant, theoretically in the first stage of the examination, the suspect / defendant already has a position that is equal with the examiner officials in terms of legal position. He has the right to demand treatment outlined in the Criminal Procedural Law (Yahya Harahap,1995: pp. 3-4).

The set of rights of suspects / defendants who had been formulated by the legislators and has been manifested in the wording of the articles of the Criminal Procedural Law is quite different from the provisions of the old Criminal Procedural Code called HIR. However it does not necessarily mean that the rights of suspects / defendant who has been formulated in the Criminal Procedural Law be implemented. In practice, in the implementation of the Criminal Procedural Law the suspect / defendant is not so easy to get their rights. For example, concerning the rights to be acquitted from charges. Even when the proceedings and the evidence presented before trial can not convincingly prove the criminal charges, the prosecutor will likely be bound by the Circular Attorney General of the Republic of Indonesia number: SE-001 / JA / 4/1995 on Guidelines for Criminal Charges, and in a way or another will still submit that the defendant be found guilty and sentenced by the judge.

This is worsened by the obligation of the prosecution to file an appelate measure if the verdict in a general criminal case is less than $1 / 2$ (one half) of the prosecutor's petition, and the judge's decision in a special criminal case is less than $2 / 3$ (two thirds) of the prosecutor's petition There is also an obligation to file a cassation if the judge's decision acquit the accused. Another improper rule is that the prosecutor is obliged to apply for cassation if the judge's decision in the form of acquittal. This rule is inappropriate in the light of Article 244 Criminal Procedural Law which explicitly define as follows: "Against the decision of the criminal case that was given at the last level by courts other than the Supreme Court, the defendant or the prosecutor may file a request for examination of cassation to the Supreme Court, except if the verdict is an acquittal of the accused." (Abdul hakim G. Nusantara dkk, 1996: 81). 


\section{Some Critical Notes on the Prosecution Policy of the Public Prosecutor's Office in Relation to the Presumption of Innocence Principle}

Having described the meaning of the principle of presumption of innocence including its function in the Criminal Procedural Law, in this part the author will explain about the policies applied in the prosecution of the Attorney General of the Republic of Indonesia. In accordance with the author's description at the previous part, the legal materials employed to explain the prosecution policy of the Attorney General of the Republic of Indonesia are Circular Letters issued by the Attorney General of the Republic of Indonesia. In this discussion the author will criticize the substance of SEJA that potentially violates the presumption of innocence principle.

\section{a. Circular of the Attorney General of the Republic of Indonesia Number: SE-009 / JA / 12/1985 on Guidelines for Criminal Charges (December 14, 1985).}

Circular of the Attorney General titled Criminal Prosecution Guidelines was issued on December 14, 1985 based on the results of assessment that there has been no uniformity / unity of the weight of the criminal charges filed by the public prosecutor for similar cases, circumstances and motive. In addition, criminal charges filed by the public prosecutor deemed too light both in terms of the maximum criminal penalty as well as in terms of developing a sense of justice in society.

Guided by the principle of 'ATTORNEY IS ONE AND INDIVISIBLE', uniform policy is required in filing criminal charges, especially considering that the Circular Letter of the Minister of the Attorney General No. I / SE / Secr / 1963, dated January 3, 1963, which outlined guidelines on the severity of the punishment demanded by the public prosecutor is no longer relevant.

In principle this Circular contains 8 (eight) points that must be considered in the prosecution, namely:

1) In the case where aggravating factors are more dominant, then the guidelines of criminal charges is the maximum corporal penalty governed by relevant articles of the legislation concerned. 
2) When the mitigating factors are more dominant and the relevant articles in the violated legislation do not set death penalty, the criminal prosecution should consider whether the crimes involved belong to the general or special offenses:

a. For general offences, in principle the criminal charges are 2/3 (two thirds) of the maximum imprisonment as stipulated in article of the relevant legislation.

b. For a special criminal offenses, in principle the criminal charges are $3 / 4$ (three quarters) of the maximum imprisonment as governed by the article of the legislation concerned.

3) In the case there are more than one corporal punishment governed by the article of the legislation concerned, such as, among others, Article 340 of the Criminal Code that specifies a sentence of death or life imprisonment or imprisonment for ever 20 years, the guidelines require the following charges:

a. In a case where the aggravating factors are more dominant, the criminal charges should be the first most severe alternative punishment, namely the death penalty.

b. In terms of mitigating factors are more dominant, the criminal charges should be the second or third alternative punishment, according to the weight of the mitigating factors.

4) If in the law in question stipulates additional penalties, the criminal charges should also include them.

5) The severity of the penalty should reside in the realm of the discretion of the Head of Prosecutor / Head of the District Attorney Office.

6) In determining the severity of the criminal charges the following factors need to be considered:
a) the Perpetrator;
b) the criminal act;
c) the result of the crime;
d) other factors.

7) In the event that there is any particular considerations so that the Head of the High Prosecutor Office / Head of District Prosecutor Office argues that there 
should be a deviation from the guidelines outlined in this Circular Letter, the possibility of deviation should be consulted with the Attorney General along with an explanation of such considerations.

8) The guidelines of criminal charges do not apply to cases of subversion. Such cases are to be controlled directly by the Attorney General of the Republic of Indonesia since subversions are undermining Pancasila as the state ideology and the Constitution of 1945, as well as concerning the very existence of the Republic of Indonesia.

\section{b. Circular of the Attorney General of the Republic of Indonesia Number: SE-001 / J-A / 4/1995}

This Circular of the Attorney General, titled the Guidance for Criminal Charges, was published on April 27, 1995. The Circular was published due to the reports received and observations conducted regarding criminal charges filed by the Prosecution which so far has not met the expectations. It is deemed necessary to improve the criminal charges guidelines set forth in the Circular of the Attorney General of the Republic of Indonesia Number: SE-003 / JA / 8/1988 with a view:

1) to better meet the sense of fairness that live and thrive in the community.

2) to provide deterrent for the perpetrators of criminal acts, to provide preventive effect and deter others from conducting crimes.

3) to create unity in prosecution policy in line with the principle that the Prosecutor is one and indivisible.

4) to avoid disparities in criminal charges for similar cases take place in different locations by taking into account particularities in any criminal case. The Circular of the Attorney General basically contains two (2) points, namely criminal prosecution guidelines for general crime and criminal prosecution guidelines for special crimes, which is outlined as follows:

1) Guidance for criminal prosecution for general crimes, contains:

a) Factors to be considered include:

(1) the act of the perpetrator;

(2) the personality of the perpetrator;

(3) the impact of the act performed. 
b) Criminal charges, which contains about when the Prosecution should demand:

(1) death penalty;

(2) lifetime imprisonment;

(3) penalty at least $1 / 2$ of the punishment stipulated in the relevant article;

(4) penalty at least $1 / 4$ of the punishment stipulated in the relevant article;

(5) conditional punishment

c) The procedure for filing criminal charges.

d) Decision review measure.

In filing an appeal, the following matters should be considered:

(1) If the defendant appealed, the Public Prosecutor must request an appeal in order to enable the use of cassation according to the provisions of Article 43 of the Law No. 14 of 1985 on the Supreme Court.

(2) If the verdict of the judge is less than the death penalty or life imprisonment, but at least provide 20 years imprisonment, and if the public prosecutor's consideration are taken over partially or entirely as a consideration of the judge in his ruling, the Public Prosecutor should not file an appeal.

(3) If the verdict of the judge is a half of the demands of the public prosecutor, and if the public prosecutor's consideration in criminal charges was taken partly or wholly by the judge in its decision, the public prosecutor does not have to file an appeal.

(4) If the verdict of the judge is $2 / 3$ (two thirds) of the demands of the public prosecutor, even if the consideration of the public prosecutor is not taken partly or in whole by the judge in its decision, the public prosecutor does not have to file an appeal.

(5) Request for cassation should be filed by the Public Prosecutor if the court decision acquit the defendant amar and if reasons as referred to in Article 253 paragraph (1) of the Criminal Procedural Law exist.

2) Guidance for criminal prosecution of special crimes, contains:

a) Factors to be considered include: 
(1) the act of the perpetrator

(2) the personality of the perpetrator;

(3) the impact of the act performed.

b) Criminal charges, which contains rules about when the Prosecution should demand:

(1) Control of criminal prosecution by the Attorney General;

(2) Control of criminal charges by the High Prosecutor's Office;

c) The procedure for filing criminal charges.

d) Decision review measure

(1) If the defendant appeals, the public prosecutor must appeal in order to enable the use of cassation;

(2) If the judge's ruling is lower than $2 / 3$ (two thirds) of criminal charges Prosecution.

(3) If the court punish the defendant to serve 20 (twenty) years imprisonment or less than 20 (twenty) years in prison, while the demands of the prosecution is death penalty.

(4) If the court punish the defendant to serve 20 (twenty) years imprisonment, while the demands of the prosecution is lifetime imprisonment.

(5) Request for cassation review should be filed by the public prosecutor if the court decision acquit the defendant, and the reasons as referred to in Article 253 paragraph (1) of the Criminal Procedural Law exist.

\section{c. Circular of the Attorney General of the Republic of Indonesia Number: SE-001 / JA / 2/1999}

This Circular of the Attorney General titled Conditional Sentencing Guidelines for Prosecution of Corruption Cases, wass issued on February 5, 1999. The Circular is published based on reports received and observations conducted which revealed that in prosecuting corruption cases, there are a substantial number of prosecutors who charge the defendant with conditional punishment which essentially included in the category of imprisonment. However, considering that the corruption cases is a severe criminal offense usually draw public attention, firm legal response is required to implement People's Assembly Decree No. XI / 
MPR / 1998 regarding the Clean Governance Free of Corruption, Collusion and Nepotism.

Conditional sentence for the perpetrators of corruption has been perceived as too delicate by the community. Thus, the conditional sentence by the public prosecutor need to be managed with a view to realizing the prosecution in accordance with the development of the community. Hence, the Code of Criminal Charges as stipulated in Circular Letter No. SE-Attorney General 001 / JA / 4/1995 dated 27 April 1995 (Chapter II case for Special Crimes, criminal charges item B) need to be equipped with rules on a conditional sentencing in a corruption cases.

\section{d. Circular of the Attorney General of the Republic of Indonesia Number:} SE-003 / A / JA / 05/2002

This Circular of the Attorney General, issued on 13 May 2002, is titled Amendment of Control of Charges for Special Crimes. This Circular Letter was issued following the recommendation of the Working Group of the Attorney General of the Republic of Indonesia on 15 - 16 April 2002 and also based on the observations and reports concerning the issue, as well as on the need to anticipate the demands of society for law enforcement in the case of Special Crimes. It was believed that further efforts should be made to accelerate the settlement of cases in question.

In respect of this issue, the control mechanism for prosecution of Special Crimes stipulated in the Circular of the Attorney General of the Republic of Indonesia Number: SE-001 / JA / 4/1995 dated April 27, 1995 need to be adjusted and refined, which involves:

1) Criminal prosecution

a) the Attorney General take control of the criminal charges of the public prosecutor in the following cases:

(1) crime of smuggling of goods which involve the value of Rp. 1.000.000.000.00 (one billion rupiah) or more;

(2) crime of territorial intrussion and violation of State interests in Indonesian Economic Exclusive Zone; 
(3) cases of corruption involving state losses of $\mathrm{Rp}$. 1.000.000.000.00 (one billion rupiah) or more;

(4) other special crimes that draw public attention at the national or international scale or because of certain causes that demand that the prosecution be done by the General Attorney Office.

b) Other cases

(1) crimes of smuggling involving the value of Rp. 100,000. 000.00 (one hundred million rupiah) up to approximately Rp. 1,000,000,000.00 (one billion rupiah) shall be controlled by the High Prosecutor Office, while those involving the value less than Rp. 100.000.000.00 (one hundred million rupiah) shall be controlled by the District Prosecution Office.

(2) cases of corruption resulting in state losses of Rp. 100.000.000.00 (one hundred million rupiah) up to approximately Rp. 1000 to $000,000.00$ (one billion rupiah) shall be controlled by the High Prosecutor's Office, while those involving state losses less than Rp. 100.000.000.00 (one hundred million rupiah) shall be controlled by the District Prosecution Office.

2) Decision review measure

a) In filing an appelate request, the following aspects should be taken into considerations:

(1) the verdict of the judge is lower than $2 / 3$ (two thirds) of the sentence prayed for by the prosecution,

(2) the verdict of the judge involves 20 years imprisonment or less than 20 years in prison, while the demands of the public prosecutor is the death penalty,

(3) the verdict of the judge is less than 20 years imprisonment while the public prosecutor demanded life imprisonment;

(4) if the defendant appeals, the public prosecutor does not have to appeal except in the matters stipulated in the first 3 points above, since the request for cassation can only be made when one party has been using an appeal (vide Letter of Deputy Attorney General No. B -195 / E / 
Efk / 4/96 dated 17 April 1996 regarding the understanding of the intent of Article 43 of Law No. 14 of 1985 on the Supreme Court).

(5) Request for cassation shall be filed by the prosecutor if the verdict of the judge acquitted the defendant and the reasons referred to in Article 253 paragraph (1) Criminal Procedural Law exist.

3) With the issuance of this Circular, matters set out in the Circular of the Attorney General Number: SE-001 / JA / 4/1995 dated 27 April 1995 on Guidelines for Criminal Charges which is contrary to this Circular are declared invalid.

e. Circular of the Attorney General of the Republic of Indonesia Number: SE-005 / A / JA / 08/2003

This Circular of the Attorney General, entitled on the death penalty, dated February 5, 1999, was issued based on the pros and cons among the academia, Non-Governmental Organizations (NGOs) and practitioners concerning the application of the death penalty in corruption cases, so that the implementation of this penalty shall be done carefully and selectively.

In the application of the death penalty, the prosecutor shall refer to the Circular of the Attorney General of the Republic of Indonesia Number: SE-001 / JA / 4/1995 on Guidelines for Criminal Charges by submitting a prosecution plan in sequential order from the public prosecutor, head of general crime section, Head of District Prosecutor Office, Head of High Prosecutor Office and the Attorney General of the Republic of Indonesia. The prosecution plan shall include juridical reasons and other considerations underlying the public prosecutor filed a death penalty. Thus the public prosecutor could only demand death penalty in his prosecution upon to the approval of the Attorney General of the Republic of Indonesia.

f. Circular of the Attorney General of the Republic of Indonesia Number: SE-006 / A / JA / 08/2003

This Circular of the Attorney General on Acquittal was issued on August 25,2003 , following the rise of the public response to demands for acquittal in the case of Tempo Magazine To avoid confusion between the opinion of the prosecutors, it is deemed necessary to convey the following matters: 
1) that basically the prosecutors are not allowed to demand acquittal in a case considering the duties and authority to prosecute criminal cases, (Article 182 (1) a Criminal Procedural Law).

2) that since witness testimony as evidence is what the witness stated in court (Article 185 Criminal Procedural Law), public prosecutor is allowed to demand acquittal in a case of withdrawal of testimony in court leaving that there is no other evidence.

3) that prior to demand for acquittal, the following steps should be taken:

a. strongly implement the instructions Attorney General for General Crimes contained in the following in the letter:

(1) Number: B-401/E/9/1993 dated 8 September 1993, Re: Preprosecution duties

(2) Number: B-1 207/E/12/1999 dated 20 December 1999, Re: Thoughtfullness in issuing P-21 and P-22 criminal prosecution.

(3) Number: B-254/E/5/1993 dated 31 May 1993, Re: Steps to anticipate withdrawal of the testimony of witnesses before the court.

b. If the steps as referred to in item a has been implemented optimally, but the results still indicate a lack of evidence and the Prosecution believes that the defendant will be acquitted, the public prosecutor concerned is required to report to the head of general crime section, Head of District Prosecutor Office, Head of High Prosecutor Office and Attorney General of the Republic of Indonesia in sequence and to convince the superior that exposure of the case in question is possible.

4) After the exposure of cases and consultation with the superior shows acquittal could be demanded, the public prosecutor may demand acquittal.

In addition to prosecution policy stated in SEJA, the Attorney General of the Republic of Indonesia also issued letters addressed to the Head of High Prosecutor Office, namely:

a. Letter of the Attorney General to the Head of High Prosecutor Office, No. B-572 / E / 10/1994, dated October 7, 1994, Re: Failure in Prosecution. 
b. Letter of the Attorney General To the Head of High Prosecutor Office, No. B-576 / E / 10/1994, dated October 10, 1994, Re: Accomplishment of the Prosecutor in the implementation of law, enforcement of law and providing legal services.

Both letters of the Attorney General of Indonesia are in fact also be interpreted as contain prosecution policy because they provide the criteria for categorizing whether the prosecution is successful or failed. In addition, both letters form the basis for assessing the performance of the prosecutors under the office of the Attorney General of the Republic of Indonesia in carrying out the functions and authority in the field of prosecution.

From the description of the substance of SEJA concerning prosecution guidelines that must be followed by the public prosecutor in conducting the prosecution, the analysis linking the prosecution to the presumption of innocence principle could be describedas follows. Out of six SEJA, two of SEJA, namely SEJA Number: SE-009 / JA / 12/1985 and SEJA Number: SE-001 / J-A / 4/1995 use the letter head subject concerning Criminal Prosecution Guidelines. SEJA Number: SE-001 / J-A / 4/1995 replaced SEJA Number: SE-009 / JA / 12/1985 due to the reports that the criminal charges filed by the prosecution have been far from the expectations.

Traced backwards, the existence of SEJA Number: SE-001 / JA / 4/ can not be disconnected from the letter of the Attorney General addressed to the Head of High Prosecutor Offices throughout Indonesia Number. B-572 / E / 10/1994 dated October 7, 1994 on Failure in and the Attorney General letter addressed to the Head of High Prosecutor Offices throughout Indonesia No. B-576 / E / 10/1994 dated October 10, 1994 about the Accomplishment of the Prosecutor in the implementation of law, enforcement of law and providing legal services. Both letters indicate that a prosecution is failed when the judge acquitted or freed the defendant from all lawsuits, and said to be accomplished when all considerations of the public prosecutor are taken over by the judge in the verdict and when the defendant was convicted and sentenced.

If SEJA Number: SE-001 / JA / 4/1995 is seen in connection with the two letters of the Attorney General to the Head of High Prosecutor Office, it means 
that once the prosecutor receives the case files at the second stage of the investigation, what is on the mind of the public prosecutor is that the suspect is guilty of the offense as alleged by investigators. In other words, if the case file of the investigation has been declared P 21 by the public prosecutor, the public prosecutor is compelled to meet the wishes of the Attorney General as contained in the Letter of the Attorney General addressed to the Head of High Prosecutor Office throughout Indonesia No. B-576 / E / 10 / 1994 dated October 10, 1994, and prevent failure in the prosecution as stated in the letter addressed to the Attorney General the Head of High Prosecutor Office throughout Indonesia No. B-572 / E / 10/1994 dated October 7, 1994.

What is described above is not baseless, since further examination will likely show that apparently regardless of the outcome of court examination by presenting evidence, it can be said to be $99 \%$ of the public prosecutor will file criminal charges and plead that the defendant was found guilty of committing criminal offenses as charged and that the defendant be sentenced to pay the court costs.

Two SEJA that provide guidelines for criminal prosecution are quite peculiar for some reason. First, SEJA Number: SE-001 / JA / 4/1995 on Guidelines for Criminal Charges and Letter of the Attorney General addressed to the Head of High Prosecutor Office throughout Indonesia No. B-572 / E / 10/1994 dated October 7, 1994 about the failure in the prosecution, as well as the Letter of the Attorney General addressed to the Head of High Prosecutor Office throughout Indonesia No. B-576 / E / 10/1994 dated October 10, 1994 concerning the Accomplishment of the Prosecutor in the implementation of law, enforcement of law and providing legal services did not take the principle of presumption of innocence into consideration although this principle is one of the fundamental principles in the Criminal Procedural Law of Indonesia.

Unfortunately the SEJA has raised the impression that on every case that has been filed by the public prosecutor to the court, the prosecutor's main "duty" is to plea that the defendant is guilty of committing a crime indicted and sentenced by the judge. In the view of the Universal Declaration of Human Rights, the SEJA Number: SE-001 / JA / 4/1995 on Guidelines for Criminal Charges is contrary to 
Article 11 (1) which provides: "Every person accused of a criminal offense is entitled to be considered innocent until proven guilty according to law in a public trial at which he has to get all the guarantees necessary for his defense. " (Koenarto, Jend. Pol. (Purn), 1996:67-68).

Likewise similar conclusion could be drawn when the SEJA are connected with the wording of Article 17 of Law No. 39 of 1999 on Human Rights, which reads:

Everyone, without any discrimination, has the right to obtain justice by filing a petition, complaint, and a lawsuit, in criminal cases, civil, and administrative and prosecuted through the judicial process is independent and impartial, in accordance with the procedural law that ensures inspection objective by judge honest and fair to obtain a fair and correct decision.

Article 17 of Law No. 39 of 1999 suggests that the judicial process must be run in accordance with the Criminal Procedure. It means that all matters that are contrary to the Criminal Procedural Law, including SEJA, should not be the main reference of the public prosecutor in performing his prosecution duty in the criminal justice process.

Secondly, SEJA Number: SE-001 / JA / 4/1995 on Guidelines for Criminal Charges particularly with respect to obligations of the public prosecutor to file an appeal against the acquittal is contrary to Article 244 Criminal Procedural Law, which expressly provided that against the acquittal could not be submitted cassation. This means that the existence of SEJA Number: SE-001 / JA / 4/1995 on Guidelines for Criminal Charges disregards the presumption of innocence principle. What is more absurd is that if the prosecution has request for a cassation against the acquittal and such request is rejected by the Supreme Court, by virtue of the letter of the Attorney General addressed to the Head of High Prosecutor Office throughout Indonesia No. B-533 / E / EPL / 10/1993 dated 30 October 1993 on the Cassation against Acquittal, what is done by the public prosecutor will likely be categorized as a failure.

This fact has basically confirmed the assumption that in performing their duty the prosecutor is no longer subject to the principle of presumption of innocence guaranteed in the Criminal Procedural Law. Instead, the prosecutors are 
bound more by SEJA and letters of the Attorney General. In fact, theoretically, SEJA and Letter of the Attorney General are not part of authoritative legislation. Therefore, according the principle of legality, what is already regulated in the Criminal Procedural Law should guide the Public Prosecutor in carrying out the functions and authorities in the field of prosecution. Otherwise, that such actions will blatantly violate the law.

\section{Change in Prosecution Policy of the Attorney General to Align with the Principle of Presumtion of Innocence}

The results of the above analysis indicates a very serious institutional problems within the institution of Attorney General of the Republic of Indonesia. "Violation" of the presumption of innocence principle in the prosecution policy applicable in office of Attorney General is an issue that should be settled and should be discontinued. The solution to the problem itself is actually very simple: the prosecution policy in the office of Attorney General of the Republic Indonesia is not the law, for the law is Criminal Procedural Law accordance with the principles of legality. Thus, returning to the Criminal Procedural Law is the proper solution, since this problem will not arise when the normative nature of the Criminal Procedural Law is correctly taken into consideration, in particular the internal logic of the provisions contained therein.

With particular regards to the prosecution, the Criminal Procedural Law has set in Article 182 of the Criminal Procedural Law the following rules:

(1)

a. After an examination has been declared completed, the public prosecutor shall put forward his criminal charges.

b. The defendant and/or his legal adviser shall state their defense which can be replied by the public prosecutor with the stipulation that the, defendant or his legal adviser shall always be given the last turn.

c. Charges, defence and reply to the defence shall be in writing and after having been read out they shall be handed over immediately to the judge/chairman of the session and the copies to the parties concerned.

(2) If the procedure mentioned in paragraph (1) has been completed, the judge/chairman of the session shall declare the examination closed, with 
the provision that it can be reopened once again, whether by authority of the judge/chairman of the session because of his function. or at the request of the public prosecutor or the defendant or the legal adviser by giving the reason.

(3) The judge shall then hold final consultations to take a decision and if necessary the consultations shall be held after the defendant, legal adviser, public prosecutor and those present have left the session room.

The provisions of Article 182 paragraph (1) of the Criminal Procedural Law raises the thought that the prosecution policy of the Attorney General of the Republic of Indonesia should be based on the presumption of innocence developed from systematic interpretation within the framework of internal logic contained in the Criminal Procedural Law itself.

First of all, the types of court rulings in criminal justice should be assessed. According to Article 1 point 1 of the Criminal Procedural Law: "The court verdict is a statement of the judge pronounced in open court, which can be either criminal prosecution or free or free from all charges in the case and in the manner set forth in this law." In relation to the types of verdict, the Criminal Procedural Law in Article 191 describes as follows. First, acquittal verdict which may be adopted "[i]f the court believes that the results of the examination in the trial, the guilt of the accused for the actions against her is not proven legally and convincingly." (Article 191 paragraph (1) of the Criminal Procedural Law) Secondly, verdict that release the defendant from all charges, "[i]f the court believes that the actions of which the accused defendant is proven, but the act did not constitute a criminal offense." (Article 191 paragraph (2) of the Criminal Procedural Law) Third, verdict that determine punishment, if the results of the examination in the trial, the guilt of the accused for the actions is proven legally and convincingly (Article 193 of the Criminal of the Criminal Procedural Law).

Accordingly, depending on the the provisions described above, the examination at the trial, particularly the results of the evidence, shall determine the type of verdict. As a rule, the result of the examination should not only bind the judge in making verdict, but should also bind the public prosecutor submitting 
criminal charges after the examination is completed (in this case is the evidence examination).

Therefore, when the practice as intended by SEJA takes place, it appears in the public eye as if the office of the prosecutor demonstrate arrogance by disregarding the principle contained in the Criminal Procedural Law. When the public prosecutor still file a claim requesting that the court impose punishment while the results of evidence runs contrary, this action reflects disrespect to the results of the court examination over the evidence. Thus, the existence of SEJA as the basis for prosecution policy is illogical since it is against to the Criminal Procedural Law, in which a judge is obliged to abide and be bound by the results of the court examination, while SEJA instructs otherwise to the public prosecutor.

Based on these arguments the author proposes ideas concerning the rules that should be held firmly by the public prosecutor. As has been described previously, the rule is that the submission of acquittal in the prosecution is possible, even it is an obligation if the court examination over the evidence shows that the guilt of the accused could not be proven legally and convincingly. In other words, according to this principle, the defendant has the right to be acquitted if the prosecution could not legally and convincingly prove that the defendant has committed the crime for which he was charged.

The reason for the author to propose this rule is to improve the criminal justice process so that it is consistent with the rules of the Criminal Procedural Law. The improvements that the author intended is development of positive image of the prosecutor institution which is far from the impression of arrogance, selfjustification and arbitrary. The concrete form of the improvement is that the prosecutor acted carefully and cautiously to file a case to the court in terms that the filed case should be completely equipped with adequate evidence to prove the guilt of the accused beyond reasonable doubt. Strictly speaking, the prosecutor should be very selective in processing the case to avoid the practice of "makingup" the evidence (or the ways to collect evidence) which would result in miscarriage of justice, because there will be people, most likely innocent ones, sacrified in the made-up justice. 


\section{CLOSING}

Based on the results of the discussion and analysis, it can be concluded that the prosecution policy applicable in office of prosecutor of the Republic of Indonesia is incompatible with the principle of the presumption of innocence. In carrying out the prosecution, the prosecutor feels to be bound more by SEJA Number: SE-001 / JA / 4/1995, the Letter of Attorney General No. B-572 / E / 10/1994 and Letter of Attorney General No. B-576 / E / 10/1994 than by Criminal Procedural Law which is developed on the foundation of the principle of presumption of innocence.

Based on these conclusions, the author recommends the following:

1. In order to improve the Criminal Procedural Law, the legislators should emphasize that the principles in the Code of Criminal Procedure, in particular the presumption of innocence, shall guide the law enforcement officials at all stage of examination.

2. SEJA and letters of Attorney General that are inconsistent with the presumption of innocence principle should be revoked so as not to restrain the public prosecutor in the prosecution.

3. In order to improve the Criminal Procedural Law, to avoid multiple interpretations of the meaning of Article 181 paragraph (1) letter a of the Criminal Procedural Law, the legislators should formulate a provision that contains guidelines for criminal prosecution, as well as guidelines applicable to judges in deciding the case as stipulated in Article 191 and Article 193 of the Criminal Procedural Law.

\section{BIBLIOGRAPHY:}

Abdul Hakim G. Nusantara dkk, 1996, KUHAP Kitab Undang-Undang Hukum Acara Pidana dan Peraturan Pelaksana, Djambatan, Jakarta.

Andi Hamzah, 1983, Pengantar Hukum Acara Pidana Indonesia, Ghalia Indonesia, Jakarta.

Koenarto, Jend. Pol. (Purn), 1996, Ikhtisar Implementasi Hak Asasi Manusia dalam Penegakan Hukum, Jakarta.

M. Haryanto, 2007, Hukum Acara Pidana, Fakultas Hukum Universitas Kristen Satya Wacana, Salatiga. 
Mien Rukmini, 2003, Perlindungan HAM Melalui Asas Praduga Tidak Bersalah dan Asas Persamaan Kedudukan dalam Hukum Pada Sistem Peradilan Pidana Indonesia, Alumni, Bandung.

Soedjono Dirdjosisworo, 1984, Filsafat Peradilan Pidana dan Perbandingan Hukum, Armico, Bandung.

Teguh Prasetyo, 2002, Sari Hukum Acara Pidana 1A, Mitra Prasaja Offset, Surakarta.

Yahya Harahap, 1985, Pembahasan Permasalahan dan Penerapan KUHAP Jilid I, Pustaka Kartini, Jakarta. 